\title{
Differences in utilisation of asthma drugs between two neighbouring Swedish provinces: relation to prevalence of obstructive airway disease
}

\author{
L Larsson, G Boëthius, M Uddenfeldt
}

\begin{abstract}
Background - Considerable variation exists in the use of antiasthmatic drugs in different counties in Sweden. The reasons for this variation are unknown. A study was performed to determine if there is an association between sales of antiasthmatic drugs and the prevalence of obstructive airway diseases in two adjoining Swedish counties.

Method - The prevalence of asthmaassociated symptoms in the county of Jämtland where there is high drug use, and the county of Gävleborg where it is lower, was assessed in 1990 by a postal questionnaire answered by 11300 subjects. Three age groups were included: all 16 year olds, $13 \%$ of those aged $30-39$ years, and $13 \%$ of $60-69$ year olds. A total of 2100 subjects reporting airway symptoms in a questionnaire and 450 asymptomatic controls were further investigated at an interview with lung function tests and, in 500 cases, with a methacholine challenge. Asthma was diagnosed in subjects reporting a typical history or repeated episodes of dyspnoea and wheezing, or dry cough combined with reversibility in $\mathrm{FEV}_{1}$, variability in peak expiratory flow, or a $P_{20}$ value of $\leqslant 4 \mathrm{mg} / \mathrm{ml}$.
\end{abstract}

Results - The prevalence of current asthma was close to $8 \%$ in all age groups in Jämtland and significantly lower (close to $6 \%$ ) in all age groups in the warmer, more industrialised and more densely populated county of Gävleborg. A gender difference with a higher prevalence in women was found in Gävleborg but not in Jämtland. There was no significant difference in the use of inhaled $\beta_{2}$ stimulants among subjects with asthma in the two counties. Inhaled steroids were used more often in Jämtland. However, they were used regularly by fewer than $10 \%$ of asthmatic subjects in the two younger age groups. Conclusion - The differences in the use of antiasthmatic drugs in these two counties reflect a difference in the prevalence of obstructive airway disease.

(Thorax 1994;49:41-49)

The prevalence of asthma varies considerably between regions and over time. ${ }^{1}$ There is no systematic pattern in these variations except for a rising prevalence reported in most countries. This may be partly the result of an increasing awareness of respiratory problems and a tendency, even in less severe cases, to label patients as asthmatic. There are few reliable data on prevalence from studies using comparable methodology in different regions. The use of antiasthmatic medication is one indicator of the prevalence of obstructive airway diseases, although it is clearly influenced by a number of other factors such as the organisation and accessibility of health care, awareness of respiratory problems in the population, and the tendency among health professionals to treat these symptoms pharmacologically.

Sales of antiasthmatic drugs in the county of Gävleborg are only $60 \%$ of those in the county of Jämtland. We have reported previously the results of a postal questionnaire in these two areas to assess the prevalence of airway symptoms as a possible cause of differences in the use of antiasthmatic drugs. ${ }^{2}$ A higher cumulative prevalence of asthma, as well as prevalence of current asthmatic symptoms, was found in the less industrialised and urbanised but colder county of Jämtland. We concluded that the differences in drug use reflect this difference.

In order to study to what extent these differences also reflect a difference in prevalence of obstructive airway disease and to what extent drug treatment had actually been used, we interviewed and tested lung function in 2106 symptomatic and $\mathbf{4 5 8}$ asymptomatic subjects as controls. The results of these examinations are reported here.

\section{Methods}

Subjects were selected from the responders to a postal questionnaire sent to all those aged 16 years, $13 \%$ of those aged $30-39$ years, and $13 \%$ of those aged 60-69 in the county of Jämtland and Gästrikland, the southern part of the county of Gävleborg, in February 1990. The study population has been described elsewhere. ${ }^{2}$

SELECTION FOR INTERVIEW AND EXAMINATION The 22 item questionnaire included questions on: previous history of asthma or chronic bronchitis; use of antiasthmatic medication; physician's diagnosis of asthma, chronic 
bronchitis, or emphysema; attacks of dyspnoea, shortness of breath or breathlessness; wheezing in the chest; and prolonged productive cough.

All subjects answering positively to any of these questions were invited to undergo a further examination. In addition, subjects reporting productive cough of any duration were invited if any other airway symptom was reported. Subjects reporting airway symptoms provoked by external factors such as cold air, dust, smoke, or strong scents were invited if at least three of these precipitating factors were identified, or if any other airway symptom was reported.

This selection resulted in $1356(24 \cdot 2 \%)$ of the 5607 subjects from Jämtland, and 1182 $(20 \cdot 8 \%)$ of the 5687 from Gävleborg who had answered the questionnaire being invited for further examination. A random sample of $\mathbf{3 0 0}$ of those who denied symptoms in each county were selected as controls. A schematic model of the study design is shown in fig 1 .

The interviews and examinations were performed between April 1990 and September 1991, 2-17 months after the postal survey. The examinations took place at the local health care centres and were carried out by the same two nurses in each county, both of whom had long experience of treating patients with obstructive lung disease.

\section{INTERVIEW}

Each interview took approximately 30 minutes and included detailed questions on: wheezing, shortness of breath, chest tightness/chest pain; situations or agents provoking airway symptoms; cough and phlegm production; impact of symptoms on daily living; tobacco exposure, past and present, active and passive; and drug consumption.

\section{NON-PARTICIPANTS}

The interview and examinations were attended by $83 \%$ of the symptomatic subjects and by $76 \%$ of the asymptomatic controls. There were 432 non-attenders, 212 in Jämtland and 220 in Gävleborg. They were contacted by telephone and asked to respond to the questions on mediciation and symptoms. Thus, 200 of the 432 non-attenders answered the questions. Of those remaining, 88 had moved or died, 79 were not listed in the telephone directory, 38 did not answer the telephone calls, and 27 were reached but refused to participate. Non-participants in the control group were not contacted.

\section{LUNG FUNCTION TESTING}

Lung function was tested with pneumotachographs (Vitalograph Alpha) exchanged between the counties at regular intervals. Vital capacity (VC), forced vital capacity (FVC), and forced expiratory volume in one second $\left(\mathrm{FEV}_{1}\right)$ was tested before and 15 minutes after $0.6 \mathrm{mg}$ salbutamol (Ventolin) inhaled via a spacer. The ATS recommendations ${ }^{3}$ for spirometric testing were followed, except that the Vitalographs were calibrated once daily with a one litre syringe (instead of twice daily with a three litre syringe as suggested by the ATS). Normal values from Solymar et $a l^{4}$ were used in 16 year olds and those from Berglund et $a l^{5}$ in adults. Subjects using antiasthmatic medication were asked to stop inhaled $\beta$

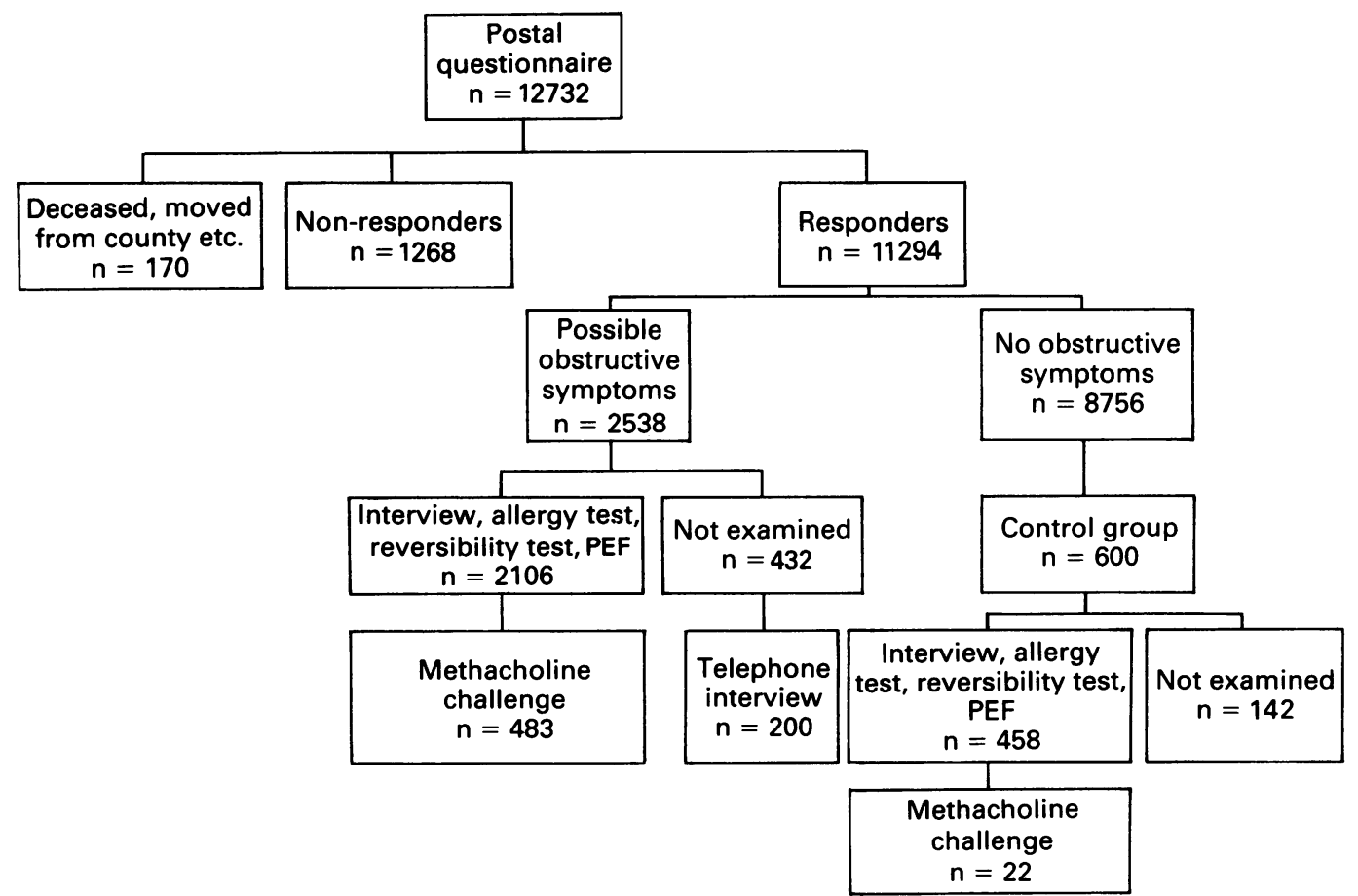

Figure 1 Schematic presentation of study. 
agonists for six hours, and systemic $\beta$ agonists or xanthines for 12 hours before the examination.

MONITORING OF PEAK EXPIRATORY FLOW

At the examination all subjects were asked to record their peak expiratory flow (PEF) for one week with mini-Wright peak flow meters as described by Higgins et al. ${ }^{6}$ On all days with at least three recordings the amplitude as a percentage of the mean of the day was calculated (highest - lowest $\times 100 /$ mean).

\section{ADDITIONAL INVESTIGATIONS}

A skin prick test was performed with Phazet using the Nordic panel of 10 common allergens. Two further questionnaires were completed, one concerning indoor climate at home, school, or work place, and one containing questions on quality of life. These investigations will be reported in separate papers.

\section{METHACHOLINE CHALLENGE}

Subjects with a history suggestive, but not diagnostic of, asthma (see diagnostic criteria below) were invited to undergo a methacholine challenge. The challenge was performed using the test protocol described by Löwhagen and Lindholm. ${ }^{7}$ Two $\mathrm{ml}$ of methacholine chloride in doubled concentrations from $0.03 \mathrm{mg} / \mathrm{ml}$ to $16 \mathrm{mg} / \mathrm{ml}$ were nebulised on demand with an Aiolos nebuliser with a mean (SD) output of $0.7(0.05) \mathrm{ml} / \mathrm{min}$ at $200 \mathrm{kPa}$ and inhaled by tidal breathing for two minutes at five minute intervals. $\mathrm{FEV}_{1}$ was recorded two and four minutes after each dose. The result was expressed as provocative concentration causing a $20 \%$ fall in $\mathrm{FEV}_{1}\left(\mathrm{PC}_{20}\right)$.

\section{DIAGNOSTIC CRITERIA}

Diagnoses were based on the criteria suggested by the ATS. ${ }^{8}$

\section{Asthma}

Asthma was diagnosed if all of the following symptoms and findings were present: repeated attacks of wheezing in the last year; repeated attacks of dyspnoea with shortness of breath in the last year; identified exogen agents (at least three, and including allergens or non-specific factors) provoking shortness of breath, wheezing, or both; complete recovery between attacks; best $\mathrm{FEV}_{1} \geqslant 80 \%$ of predicted.

If the history suggested asthma with repeated episodes of dyspnoea, wheezing in the last year, or both, and at least one positive answer to questions on wheezing or on longstanding dry cough but did not meet the above criteria, the diagnosis was confirmed by either (1) reversibility of $15 \%$ from initial value in $\mathrm{FEV}_{1}$ after salbutamol inhalation; or (2) variability in PEF $\geqslant 20 \%$ (amplitude \% mean) for three of seven days; or (3) $\mathrm{PC}_{20} \leqslant 4 \mathrm{mg} / \mathrm{ml}$ and a best $\mathrm{FEV}_{1} \geqslant 80 \%$ of predicted.

Subjects with a best FEV $1<80 \%$ of predicted and reversibility of at least $15 \%$ and 0.3 litres in absolute value, and a history suggestive of asthma, were classified as having asthma and chronic obstructive pulmonary disease (COPD). In six individuals who used antiasthma drugs but who failed to fulfil criteria for asthma (as described above) asthma was diagnosed from hospital records containing indisputable evidence of the diagnosis.

\section{$C O P D$}

COPD was diagnosed in subjects with a best $\mathrm{FEV}_{1}<80 \%$ of predicted and reversibility in $\mathrm{FEV}_{1}$ of $<0.3$ litres in absolute values or $<15 \%$ in relative values, and a history of current symptoms suggesting obstructive airway disease.

\section{Chronic bronchitis}

Chronic bronchitis was diagnosed in subjects having productive cough occurring on most days for at least three months of the year for at least two consecutive years, and a best $\mathrm{FEV}_{1}$ $\geqslant 80 \%$ of predicted. Subjects with asthma, COPD, or any other disease possibly explaining the cough were not diagnosed as having chronic bronchitis.

Airway symptoms of uncertain significance Airway symptoms of uncertain significance were considered to be present in subjects with a history suggestive of asthma, but in whom lung function, PEF recordings, or methacholine challenge failed to confirm the diagnosis of asthma.

\section{Other diseases}

Other lung diseases $(n=27)$ or diseases of other organs explaining the findings $(n=32)$ were diagnosed from the history, hospital records or, in some instances, after further examination.

The study was approved by the Ethics Committee at the University of Umeå.

\section{STATISTICS}

Differences in the prevalence between province were tested for statistical significance using the $\chi^{2}$ test, two-tailed $\mathrm{p}$ value, and Yates' correction. Differences were regarded to be significant when $\mathrm{p} \leqslant 0 \cdot 05$.

\section{Results}

\section{ASTHMA}

In all, 664 cases of asthma were found in subjects in the symptomatic group and two in the control group (table 1). In $15 \%(n=102$; 48 in Jämtland, 54 in Gävleborg) the diagnosis was based on a typical history and a best FEV $\geqslant 80 \%$ of predicted values; in 558 subjects (including the two controls) the diagnosis was confirmed by reversibility of $\mathrm{FEV}_{1}$, variability in PEF, or methacholine challenge, and in six subjects (four in Jämtland, two in Gävleborg) the diagnosis was confirmed by hospital records. 
Table 1 Investigated individuals in symptom group $(S)$ and control group (C) and number of individuals classified in diagnostic groups by age and by sex

\begin{tabular}{|c|c|c|c|c|c|c|c|c|c|c|c|c|}
\hline & \multicolumn{4}{|c|}{ Age 16 years } & \multicolumn{4}{|c|}{ Age 30-39 years } & \multicolumn{4}{|c|}{ Age 60-69 years } \\
\hline & \multicolumn{2}{|l|}{ fämtland } & \multicolumn{2}{|c|}{ Gävleborg } & \multicolumn{2}{|l|}{ fämtland } & \multicolumn{2}{|c|}{ Gävleborg } & \multicolumn{2}{|c|}{ fämtland } & \multicolumn{2}{|c|}{ Gävleborg } \\
\hline & $S=239$ & $C=73$ & $S=204$ & $C=78$ & $S=422$ & $C=91$ & $S=351$ & $C=81$ & $S=473$ & $C=67$ & $S=417$ & $C=68$ \\
\hline $\begin{array}{l}\text { Asthma } \\
\text { Males } \\
\text { Females }\end{array}$ & $\begin{array}{r}110 \\
58 \\
52\end{array}$ & $\begin{array}{l}1 \\
1\end{array}$ & $\begin{array}{l}79 \\
27 \\
52\end{array}$ & $\begin{array}{l}1 \\
1\end{array}$ & $\begin{array}{r}147 \\
71 \\
76\end{array}$ & & $\begin{array}{r}110 \\
41 \\
69\end{array}$ & & $\begin{array}{r}130 \\
55 \\
75\end{array}$ & & $\begin{array}{l}88 \\
35 \\
53\end{array}$ & \\
\hline $\begin{array}{l}\text { COPD } \\
\text { Males } \\
\text { Females }\end{array}$ & $\bar{z}$ & & $\bar{z}$ & & $\begin{array}{l}6 \\
3 \\
3\end{array}$ & $\begin{array}{l}1 \\
1\end{array}$ & $\begin{array}{r}15 \\
7 \\
8\end{array}$ & & $\begin{array}{l}79 \\
46 \\
33\end{array}$ & $\begin{array}{l}1 \\
1\end{array}$ & $\begin{array}{r}109 \\
68 \\
41\end{array}$ & $\begin{array}{l}2 \\
2\end{array}$ \\
\hline $\begin{array}{l}\text { Asthma and COPD } \\
\text { Males } \\
\text { Females }\end{array}$ & $\begin{array}{l}- \\
-\end{array}$ & & $\begin{array}{l}- \\
-\end{array}$ & & $\begin{array}{l}4 \\
3 \\
1\end{array}$ & & $\begin{array}{l}2 \\
1 \\
1\end{array}$ & & $\begin{array}{r}13 \\
6 \\
7\end{array}$ & & $\begin{array}{r}11 \\
7 \\
4\end{array}$ & \\
\hline $\begin{array}{l}\text { Chronic bronchitis } \\
\text { Males } \\
\text { Females }\end{array}$ & $\begin{array}{l}4 \\
3 \\
1\end{array}$ & $\begin{array}{l}1 \\
1\end{array}$ & $\begin{array}{r}14 \\
8 \\
6\end{array}$ & $\begin{array}{l}3 \\
1 \\
2\end{array}$ & $\begin{array}{l}56 \\
37 \\
19\end{array}$ & $\begin{array}{l}4 \\
2 \\
2\end{array}$ & $\begin{array}{l}38 \\
24 \\
14\end{array}$ & & $\begin{array}{l}64 \\
37 \\
27\end{array}$ & $\begin{array}{l}6 \\
1 \\
5\end{array}$ & $\begin{array}{l}35 \\
21 \\
14\end{array}$ & $\begin{array}{l}2 \\
1 \\
1\end{array}$ \\
\hline $\begin{array}{l}\text { ASUS } \\
\text { Males } \\
\text { Females }\end{array}$ & $\begin{array}{l}30 \\
14 \\
16\end{array}$ & $\begin{array}{l}4 \\
4\end{array}$ & $\begin{array}{r}20 \\
6 \\
14\end{array}$ & & $\begin{array}{l}77 \\
32 \\
45\end{array}$ & $\begin{array}{l}3 \\
2 \\
1\end{array}$ & $\begin{array}{l}45 \\
15 \\
30\end{array}$ & $\begin{array}{l}4 \\
1 \\
3\end{array}$ & $\begin{array}{l}68 \\
32 \\
36\end{array}$ & $\begin{array}{l}6 \\
2 \\
4\end{array}$ & $\begin{array}{l}49 \\
16 \\
33\end{array}$ & $\begin{array}{l}7 \\
5 \\
2\end{array}$ \\
\hline
\end{tabular}

COPD = chronic obstructive pulmonary disease; ASUS = airway symptoms of uncertain significance.

Mean (SD) $\mathrm{FEV}_{1}$ was $92(15) \%$ predicted before inhalation of salbutamol, rising to 99 (15)\% after salbutamol.

The number of subjects fulfilling the criteria for asthma was higher in Jämtland in all age groups (table 1). The estimated prevalence of asthma in the population was close to $8 \%$ in all age groups in Jämtland and about $6 \%$ in all age groups in Gävleborg, the differences being significant in all age groups (table 2). There were only minor differences in the prevalence of asthma within the provinces between the various age groups. The difference in prevalence of asthma, however, was mainly a result of a gender difference in Gävleborg with a lower prevalence in men. The difference was significant in the two younger age groups $(\mathrm{p}<0.01)$ and in the province as a whole $(\mathrm{p}<0.001)$.

Estimations of asthma prevalence in table 2 are not adjusted for differences in smoking habits between the counties. Such an adjustment of the prevalence in Gävleborg, using smoking habits in Jämtland as standard, would increase the figures and reduce the difference by $0.2 \%$ in 16 year olds, $0.1 \%$ in those aged $60-69$, while the adjusted figures would be unchanged in those aged 30-39 years.

Two 16 year old girls in the control group (one in each province) were diagnosed as having asthma. One had only reported cough in the postal questionnaire, while the other had not reported any respiratory symptoms but had a clear onset of asthma during the interval between the postal survey and the examination.

COPD

The prevalence of COPD was less than $1 \%$ in the younger age groups and 5-7\% with a male dominance in the 60-69 year age group (table 2). The gender difference was significant in Gävleborg but not in Jämtland. The prevalence of COPD was significantly higher in Gävleborg in those aged 60-69 years. Mean (SD) $\mathrm{FEV}_{1}$ was 59 (16)\% predicted, rising to $62(14) \%$ after inhalation of salbutamol.

Four subjects from the control group who had not reported any symptoms in the postal questionnaire were diagnosed at the interview as having COPD. All four were heavy smokers, a 38 year old woman and a 60 year old man from Jämtland, and two 60 year old men from Gävleborg.

\section{CHRONIC BRONCHITIS}

Chronic bronchitis was present in a few 16 year olds, in 9-14\% of investigated symptomatic subjects in the older age groups, and in 16 control subjects (table 1 ).

\section{AIRWAY SYMPTOMS OF UNCERTAIN}

\section{SIGNIFICANCE}

The criteria for inclusion in this category were fulfilled by 175 subjects in the symptomatic

Table 2 Estimated prevalence (with $95 \%$ CI) of obstructive airway disease in study population. Non-attenders and individuals with obstructive airway disease found in control group taken into account (\%). p value reported if $\leqslant 0 \cdot 1$

\begin{tabular}{|c|c|c|c|c|c|c|c|c|c|}
\hline & \multicolumn{3}{|c|}{ Age 16 years } & \multicolumn{3}{|c|}{ Age $30-39$ years } & \multicolumn{3}{|c|}{ Age $60-69$ years } \\
\hline & fämtland & Gävleborg & $p$ & fämtland & Gävleborg & $p$ & fämtland & Gävleborg & $p$ \\
\hline $\begin{array}{l}\text { Asthma } \\
\text { Males } \\
\text { Females }\end{array}$ & $\begin{array}{l}8 \cdot 1 \\
(6 \cdot 8-9 \cdot 4) \\
8 \cdot 1 \\
8 \cdot 2\end{array}$ & $\begin{array}{l}6 \cdot 1 \\
(4 \cdot 9-7 \cdot 3) \\
4 \cdot 3 \\
7 \cdot 9\end{array}$ & $\begin{array}{l}0.03 \\
0.002\end{array}$ & $\begin{array}{l}8 \cdot 4 \\
(7 \cdot 3-9 \cdot 6) \\
8 \cdot 3 \\
8 \cdot 5\end{array}$ & $\begin{array}{l}6 \cdot 3 \\
(5 \cdot 3-7 \cdot 3) \\
5 \cdot 0 \\
7 \cdot 4\end{array}$ & $\begin{array}{l}0.01 \\
0.003\end{array}$ & $\begin{array}{l}8 \cdot 2 \\
(7 \cdot 0-9 \cdot 4) \\
7 \cdot 0 \\
9 \cdot 5\end{array}$ & $\begin{array}{c}5 \cdot 5 \\
(4 \cdot 3-6 \cdot 7) \\
4 \cdot 7 \\
6 \cdot 2\end{array}$ & $\begin{array}{l}0.002 \\
0.04 \\
0.01\end{array}$ \\
\hline $\begin{array}{l}\text { COPD } \\
\text { Males } \\
\text { Females }\end{array}$ & $\begin{array}{l}- \\
-\end{array}$ & $\begin{array}{l}- \\
-\end{array}$ & & $\begin{array}{l}0 \cdot 7 \\
(0 \cdot 3-1 \cdot 1) \\
0 \cdot 4 \\
1 \cdot 0\end{array}$ & $\begin{array}{l}0.9 \\
(0.5-1.3) \\
0.9 \\
0.9\end{array}$ & & $\begin{array}{l}5 \cdot 3 \\
(4 \cdot 3-6 \cdot 3) \\
6 \cdot 2 \\
4 \cdot 2\end{array}$ & $\begin{array}{l}7 \cdot 5 \\
(6 \cdot 3-8 \cdot 7) \\
10 \cdot 6 \\
4 \cdot 8\end{array}$ & $\begin{array}{r}0.005 \\
<0.001\end{array}$ \\
\hline $\begin{array}{l}\text { Asthma and } \\
\text { COPD } \\
\text { Males } \\
\text { Females }\end{array}$ & $\overline{-}$ & $\bar{z}$ & & $\begin{array}{l}0.2 \\
(0.0-0.4) \\
0.4 \\
0.1\end{array}$ & $\begin{array}{l}0 \cdot 1 \\
(0 \cdot 0-0 \cdot 2) \\
0 \cdot 1 \\
0 \cdot 1\end{array}$ & & $\begin{array}{l}0.8 \\
(0 \cdot 4-1 \cdot 2) \\
0.8 \\
0.9\end{array}$ & $\begin{array}{l}0.7 \\
(0.3-1 \cdot 1) \\
0.9 \\
0.5\end{array}$ & \\
\hline
\end{tabular}

COPD $=$ chronic obstructive pulmonary disease. 

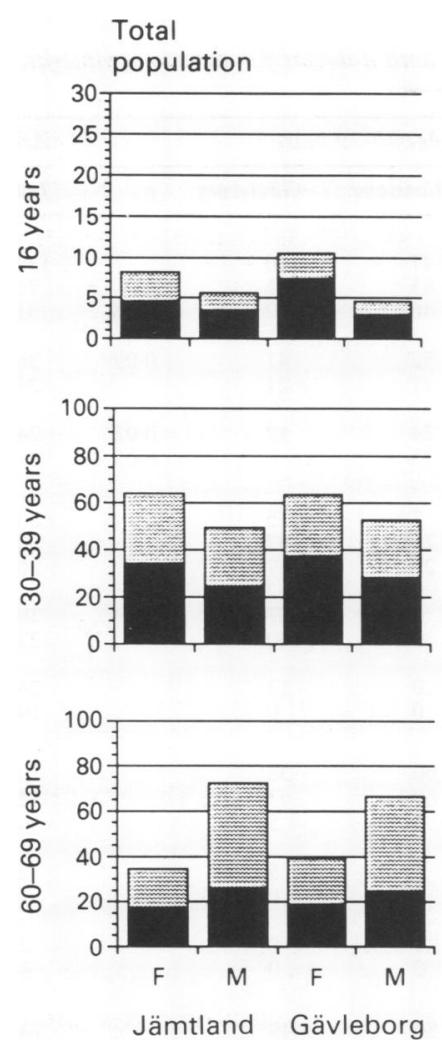
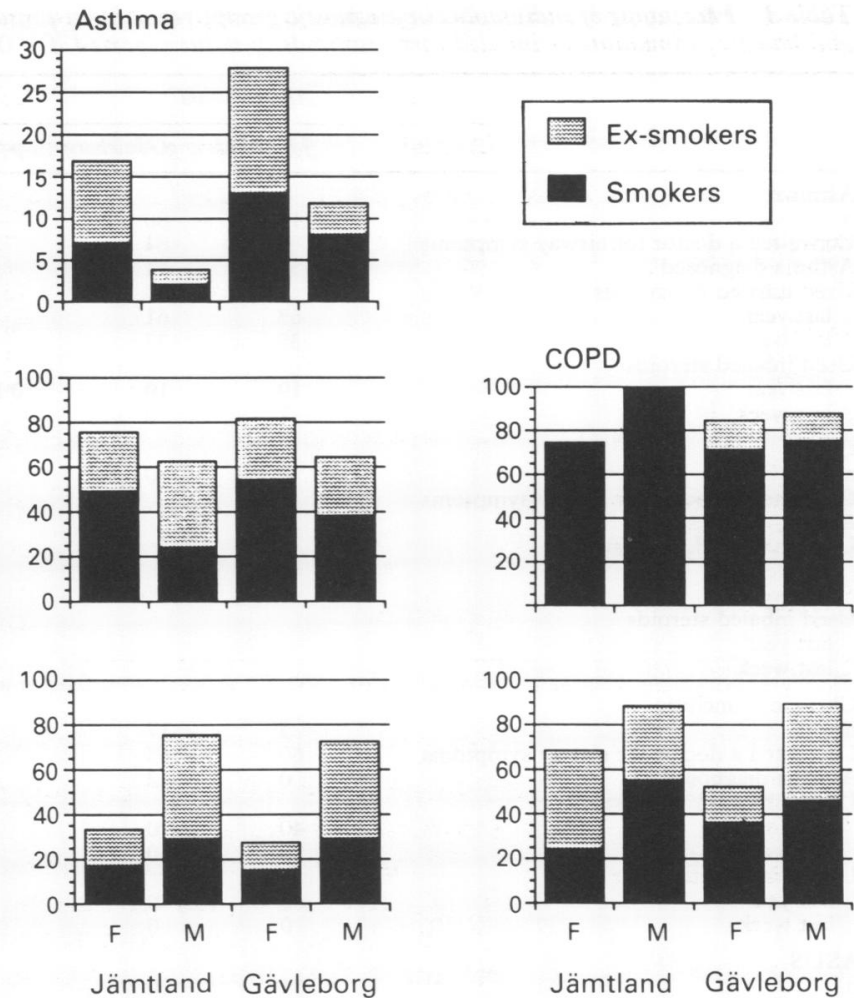

Figure 2 Prevalence (\%) of smokers and ex-smokers in total study population and in diagnostic groups by age, sex, and county. Information on smoking habits obtained from postal questionnaire. Note the divergent scale in 16 year olds.

group and by 13 in the control group in Jämtland. The corresponding figures in Gävleborg were 114 and 11 subjects (table 1 ). In this group 55 subjects were included who neither delivered a satisfactory PEF recording nor attended a methacholine challenge test, and 87 subjects with normal PEF who did not attend for methacholine challenge testing. Subjects with findings of PEF variability $(n=32)$, or $\mathrm{FEV}_{1}$ reversibility $(\mathrm{n}=26)$, or both $(n=6)$, without sufficient history qualifying for a diagnosis of obstructive airway disease, were also classified in this group. Of these 64 subjects with objective signs of variable airway obstructivity 33 were from Jämtland and 31 from Gävleborg.

\section{SMOKING HABITS}

According to the postal questionnaire about $5 \%$ of 16 year olds, $30 \%$ of $30-39$ year olds, and $20 \%$ of $60-69$ year old subjects were smokers (fig 2). The proportion of current smokers was most often higher among subjects diagnosed as having an obstructive disease, except among men in the younger age groups in Jämtland (fig 2).

\section{CONSULTATION FOR AIRWAY SYMPTOMS AND PREVIOUS DIAGNOSIS}

Over $80 \%$ of subjects with obstructive airway disease in the younger age groups, and slightly fewer in the oldest age group, had consulted a doctor about their symptoms (table 3 ). There was a tendency towards a lower consultation rate in men aged 60-69 years, particularly in smokers. This tendency was greater in those from Gävleborg. Half of the asthmatic cases among the 16 year olds reported a previous diagnosis of asthma; the corresponding figure for the older groups was slightly lower being $46 \%$ in those aged $30-39$ from Jämtland and $32 \%$ in this age group from Gävleborg $(\mathrm{p}<0.05)$.

\section{DRUG TREATMENT}

The proportion of asthmatic subjects treated with inhaled $\beta$ agonists did not differ significantly between the provinces (table 3 ). In the 30-39 year age group men were treated more often than women $(62 \% v 42 \%$ in Jämtland and $48 \% v 38 \%$ in Gävleborg in the 12 months before the study). Asthmatic subjects in Jämtland used inhaled steroids more often, the difference being greatest in the 30-39 year age group. In this age group $13 \%$ had used inhaled steroids in the week before the study and $24 \%$ in Jämtland had used them in the previous year, corresponding to $6 \%(\mathrm{p}<0.05)$ and $12 \%$ $(p<0.05)$ in Gävleborg (table 3). In the 60-69 year age group the use of antiasthmatic drugs was as common in subjects with COPD as in asthmatic subjects with no significant differences between the provinces. However, inhaled steroids were used significantly more often in Jämtland in subjects with COPD.

Few subjects not classified as having obstructive airway disease used $\beta$ agonists or inhaled steroids.

\section{AIRWAY SYMPTOMS IN NON-PARTICIPANTS}

Most questions on symptoms were answered positively by the non-participants somewhat 
Table 3 Percentage of individuals in diagnostic groups reporting a consultation with a doctor for airway symptoms, diagnosis of asthma, and use of inhaled $\beta_{2}$ stimulants or inhaled corticosteroids. $p$ value reported if $\leqslant 0 \cdot 1$

\begin{tabular}{|c|c|c|c|c|c|c|c|c|c|}
\hline & \multicolumn{3}{|c|}{ Age 16 years } & \multicolumn{3}{|c|}{ Age $30-39$ years } & \multicolumn{3}{|c|}{ Age 60-69 years } \\
\hline & fämtland & Gävleborg & $p$ & fämtland & Gävleborg & $p$ & fämtland & Gävleborg & $p$ \\
\hline $\begin{array}{l}\text { Asthma } \\
\mathrm{n} \\
\text { Consulted a doctor for airway symptoms } \\
\text { Asthma diagnosed } \\
\text { Used inhaled } \beta_{2} \text { agonists } \\
\text { last year }\end{array}$ & $\begin{array}{r}111 \\
85 \\
51\end{array}$ & $\begin{array}{l}80 \\
84 \\
54\end{array}$ & & $\begin{array}{r}147 \\
83 \\
46\end{array}$ & $\begin{array}{r}110 \\
81 \\
32\end{array}$ & 0.03 & $\begin{array}{r}130 \\
75 \\
31\end{array}$ & $\begin{array}{l}88 \\
66 \\
32\end{array}$ & \\
\hline last year & $\begin{array}{l}63 \\
35\end{array}$ & $\begin{array}{l}01 \\
37\end{array}$ & & $\begin{array}{l}52 \\
27\end{array}$ & $\begin{array}{l}41 \\
21\end{array}$ & 0.09 & $\begin{array}{l}36 \\
24\end{array}$ & $\begin{array}{l}28 \\
25\end{array}$ & $0 \cdot 1$ \\
\hline $\begin{array}{l}\text { Used inhaled steroids } \\
\text { last year } \\
\text { last week }\end{array}$ & $\begin{array}{r}19 \\
7\end{array}$ & $\begin{array}{r}10 \\
6\end{array}$ & $0 \cdot 1$ & $\begin{array}{l}24 \\
13\end{array}$ & $\begin{array}{r}12 \\
6\end{array}$ & $\begin{array}{l}0.02 \\
0.05\end{array}$ & $\begin{array}{l}24 \\
21\end{array}$ & $\begin{array}{l}23 \\
19\end{array}$ & \\
\hline $\begin{array}{l}\text { COPD } \\
\text { n } \\
\text { Consulted a doctor for airway symptoms } \\
\text { Asthma diagnosed } \\
\text { Used inhaled } \beta_{2} \text { agonists }\end{array}$ & 0 & 0 & & $\begin{array}{r}7 \\
71 \\
29\end{array}$ & $\begin{array}{l}15 \\
67 \\
47\end{array}$ & & $\begin{array}{l}80 \\
73 \\
29\end{array}$ & $\begin{array}{r}111 \\
65 \\
26\end{array}$ & \\
\hline last year & & & & $\begin{array}{l}0 \\
0\end{array}$ & $\begin{array}{l}47 \\
40\end{array}$ & & $\begin{array}{l}38 \\
23\end{array}$ & $\begin{array}{l}28 \\
19\end{array}$ & $0 \cdot 1$ \\
\hline $\begin{array}{l}\text { Used inhaled steroids } \\
\text { last year } \\
\text { last week }\end{array}$ & & & & $\begin{array}{l}0 \\
0\end{array}$ & $\begin{array}{r}13 \\
0\end{array}$ & & $\begin{array}{l}26 \\
19\end{array}$ & $\begin{array}{r}12 \\
9\end{array}$ & $0 \cdot 05$ \\
\hline $\begin{array}{l}\text { Chronic bronchitis } \\
\mathrm{n} \\
\text { Consulted a doctor for airway symptoms } \\
\text { Asthma diagnosed } \\
\text { Used inhaled } \beta_{2} \text { agonists }\end{array}$ & $\begin{array}{r}5 \\
60 \\
0\end{array}$ & $\begin{array}{l}17 \\
63 \\
12\end{array}$ & & $\begin{array}{r}60 \\
60 \\
3\end{array}$ & $\begin{array}{r}38 \\
63 \\
5\end{array}$ & & $\begin{array}{r}70 \\
52 \\
6\end{array}$ & $\begin{array}{r}37 \\
41 \\
6\end{array}$ & \\
\hline $\begin{array}{l}\text { last year } \\
\text { last week }\end{array}$ & $\begin{array}{l}40 \\
20\end{array}$ & $\begin{array}{l}0 \\
0\end{array}$ & & $\begin{array}{l}3 \\
0\end{array}$ & $\begin{array}{l}5 \\
0\end{array}$ & & $\begin{array}{l}2 \\
1\end{array}$ & $\begin{array}{l}2 \\
0\end{array}$ & \\
\hline $\begin{array}{l}\text { Used inhaled steroids } \\
\text { last year } \\
\text { last week }\end{array}$ & $\begin{array}{l}0 \\
0\end{array}$ & $\begin{array}{l}\mathbf{0} \\
\mathbf{0}\end{array}$ & & $\begin{array}{l}1 \\
0\end{array}$ & $\begin{array}{l}0 \\
0\end{array}$ & & $\begin{array}{l}2 \\
1\end{array}$ & $\begin{array}{l}0 \\
0\end{array}$ & \\
\hline $\begin{array}{l}\text { ASUS } \\
\mathrm{n} \\
\text { Consulted a doctor for airway symptoms } \\
\text { Asthma diagnosed } \\
\text { Used inhaled } \beta_{2} \text { agonists }\end{array}$ & $\begin{array}{l}34 \\
68 \\
29\end{array}$ & $\begin{array}{l}20 \\
70 \\
35\end{array}$ & & $\begin{array}{l}80 \\
72 \\
25\end{array}$ & $\begin{array}{l}49 \\
65 \\
12\end{array}$ & $0 \cdot 1$ & $\begin{array}{l}74 \\
58 \\
21\end{array}$ & $\begin{array}{r}56 \\
54 \\
2\end{array}$ & 0.004 \\
\hline last year & $\begin{array}{r}18 \\
9\end{array}$ & $\begin{array}{l}30 \\
10\end{array}$ & & $\begin{array}{r}14 \\
1\end{array}$ & $\begin{array}{r}18 \\
4\end{array}$ & & $\begin{array}{l}7 \\
3\end{array}$ & $\begin{array}{l}5 \\
0\end{array}$ & \\
\hline $\begin{array}{l}\text { Used inhaled steroids } \\
\text { last year } \\
\text { last week }\end{array}$ & $\begin{array}{l}0 \\
0\end{array}$ & $\begin{array}{l}\mathbf{0} \\
\mathbf{0}\end{array}$ & & $\begin{array}{l}2 \\
0\end{array}$ & $\begin{array}{l}2 \\
0\end{array}$ & & $\begin{array}{l}3 \\
1\end{array}$ & $\begin{array}{l}0 \\
0\end{array}$ & \\
\hline
\end{tabular}

COPD = chronic obstructive pulmonary disease; ASUS = airway symptoms of uncertain significance.

less often than by subjects attending the examination. In the past year $38 \%$ of non-participants had experienced wheeze compared with $62 \%$ of participants. Wheezing at night was, however, reported by $40 \%$ of non-participants and $32 \%$ of examined subjects. Inhaled $\beta_{2}$ agonists had been used in the week before the examination by $8 \%$ and $13 \%$, respectively. Current smoking was somewhat more common among non-participants $(32 \% v 27 \%)$.

\section{Discussion}

We have previously reported a correlation between the prevalence of asthma-associated symptoms and sales of asthma drugs in the counties of Jämtland and Gävleborg. ${ }^{2}$ In the present study we found that the differences in sales of drugs correspond to a difference in prevalence of obstructive airway disease and to treatment with inhaled steroids, which was more common among asthmatic subjects in Jämtland.

In the mid 1980s Sweden had the greatest consumption of antiasthmatic drugs per capita in Europe. ${ }^{9}$ Within Sweden, sales in Jämtland since 1980 have been $30 \%$ higher per capita than the national average. ${ }^{10}$ In spite of the high use of drugs we did not find any signs of overtreatment of asthma; in fact, less than $10 \%$ of young asthmatic patients used inhaled steroids, suggesting that many may be undertreated.
METHODOLOGICAL CONSIDERATIONS

The attendance rate at the interview and examination was quite satisfactory. Telephone interviews with non-attenders revealed a tendency towards less frequent positive answers to questions on symptoms and drug use among non-participants than among attenders. The figures on the prevalence of obstructive disease given here may consequently be a slight overestimate of the true value. In that case, however, the differences between the provinces would be underestimated as the response rate was somewhat lower in Gävleborg.

Rates of yearly incidence of asthma quoted in prospective studies in teenagers vary considerably, but have recently been reported to be $0.7 \%{ }^{11}$ In 1991 the proportion of the population aged 15-19 in Jämtland obtaining antiasthmatic drugs for the first time was $1.5 \% .{ }^{10}$ In view of this incidence the finding of two new cases of asthma in the control group was not surprising. There is probably a continual shift of subjects between the groups that we defined as "asthma" and "airway symptoms of uncertain significance." As subjects who moved from asthma to airway symptoms of uncertain significance within the year before the examination may still be classified as asthma, we have not included the two girls with newly incident asthma in the estimates of asthma prevalence.

The four cases of COPD found among smoking adults in the control group indicate a 
possible underreporting of symptoms in this group. These subjects have slowly developed symptoms of a chronic disease which were not reported in the postal questionnaire. In estimating the prevalence of COPD we have assumed an underreporting of symptoms among smokers in the proportion found in the control group, and adjusted the calculations by adding a corresponding number of cases with COPD.

As the selection of subjects from the postal questionnaire aimed at identifying subjects with obstructive airway disease, the presence of subjects with airway symptoms of uncertain significance and chronic bronchitis in the control group was not surprising. We do not believe that the methodology used allows us to make a reliable estimation of the prevalence of airway symptoms of uncertain significance or chronic bronchitis.

The problem of diagnosing asthma accurately in epidemiological studies has led to doubts about the relevance of labelling of subjects with certain symptoms and findings into one diagnostic group. ${ }^{12-14}$ In young subjects the problem is mainly to decide what degree of severity of symptoms is required to label the condition as asthma, as chronic cough has been described as the only symptom of asthma, ${ }^{15}$ while differentiation from other diseases is rarely a problem. In older subjects differentiation of asthma from other diseases, mainly COPD, is difficult and sometimes impossible. ${ }^{16}$ It seems reasonable to believe that the more detailed a study is, the larger is the proportion of "true asthmatic" subjects in the population that will be identified.

Subjects with symptoms, but without findings at examination that support a diagnosis of obstructive airway disease, are less commonly labelled. We have classified them as having airway symptoms of uncertain significance, which is neither a clinical nor an epidemiological entity, but is a very heterogeneous group and is only to be seen as a description of symptoms, the importance of which will be assessed.

As described, a "typical" history was accepted as diagnostic of asthma. This criterion has been used by Lundbäck et al in a similar study, ${ }^{17}$ and the presence of a complete history has been shown to correlate with bronchial hyperresponsiveness. ${ }^{18}$ All 16 year olds meeting our criteria of a typical history or history consistent with asthma but without antiasthma treatment in the past three months $(n=44)$ were clinically evaluated. They were all found to have clinically significant disease and were started on treatment. Of these, 26 were challenged with methacholine and all but one had a $\mathrm{PC}_{20}$ value $\leqslant 4 \mathrm{mg} / \mathrm{ml}$. One subject tested out of the pollen season did not react to a challenge with $16 \mathrm{mg} / \mathrm{ml}$, but had a significant pollen allergic asthma.

The use of PEF variability to differentiate asthmatic subjects from normal subjects was suggested by Hetzel and Clark ${ }^{19}$ and has been well documented. ${ }^{620} \mathrm{We}$ adopted the method proposed by Higgins et al. ${ }^{6}$ The criterion of $20 \%$ variability (highest - lowest $\times 100$ / mean) on three of seven days is strict, even if we did not exclude the first days' measurements as suggested by Quackenboss et al. ${ }^{20}$

The relation between asthma and bronchial hyperreactivity, as measured by methacholine challenge, has been under considerable debate. ${ }^{2122}$ Methacholine challenge is a sensitive but not very specific diagnostic tool for the diagnosis of asthma and has to be combined with a reliable history to give acceptable specificity. The problem of the "lower limit" of asthma is further complicated by the fact that some asthmatic patients seem to have poor sensitivity to bronchial obstruction, not reporting symptoms despite considerable obstruction..$^{23-25} \mathrm{~A}$ crucial point in a study of this kind is to decide what degree of symptoms is necessary to justify a diagnosis of asthma. There is no agreement on this level in the epidemiological literature. The minimum symptomatology required for diagnosis of asthma chosen in this study was repeated episodes of dyspnoea with shortness of breath spontaneously or provoked by external factors - and presence of wheeze or longstanding dry cough, which gives slightly lower prevalence figures than the definition recently suggested by Toelle et al. ${ }^{26}$

The use of hospital records to verify a diagnosis of asthma is a potential source of bias in the results. As the number of cases diagnosed this way was low, the possible impact of such a bias was very small.

Reversibility of $15 \% \%^{27}$ and increased sensibility to methacholine ${ }^{29} 30$ is frequently present in patients with COPD without indicating asthma. A variability in the PEF value has been reported in COPD $^{31}$ also limiting the value of this tool to distinguish between "pure" COPD and a combination of asthma and COPD, or longstanding asthma causing chronic obstruction with an irreversible component. A reversibility of more than $15 \%$ and 0.3 litres is, however, unlikely to be due to COPD alone. ${ }^{32}$ There are probably a number of subjects classified as COPD in this study that would reveal a reversible component in the airway obstruction if they were treated with corticosteroids for 10-20 days, justifying a classification as asthma or combination of asthma and COPD.

\section{COMPARATIVE FINDINGS}

The level of asthma found in our study is higher than that reported from Sweden 20-30 years ago $^{3334}$ and from Norway and Finland recently. ${ }^{35-37}$ The differences are probably mainly due to differences in methodology. Studies using a combination of symptoms and reversibility or bronchial reactivity to define the disease have revealed prevalences of asthma of the same level as found in this study. ${ }^{38} 39$

The difference in asthma prevalence between the provinces was mainly a result of a gender difference present in Gävleborg but not in Jämtland. This difference was significant in the two younger age groups and was present in all questions on asthma-related symptoms as 
well as in reversibility and variability, and in methacholine challenge. The reason for this difference is obscure. If men in Gävleborg underreported symptoms in the postal questionnaire a higher prevalence of obstructive subjects would be expected in the male control group in Gävleborg than in Jämtland, and at least as high a proportion of obstructive subjects in the examined symptomatic men as the women. Neither of these was the case.

Boys have been reported to have a greater prevalence of asthma than girls. ${ }^{40}$ The male dominance gradually decreases and disappears by the age of 15-17 years, ${ }^{41}$ while both male and female dominance has been reported in adults. ${ }^{142}$ In Scandinavia a female dominance has been found in 14-15 year olds ${ }^{43}$ as well as in adults. ${ }^{17333544}$ Sales of antiasthmatic drugs in Sweden are higher to boys aged 0-14 years and to men over 60 years. In $15-59$ year olds the sales are $15-25 \%$ higher to women than to men. ${ }^{10}$ The finding of a female dominance in Gävleborg fits this pattern, while the lack of gender difference in Jämtland was unexpected.

A difference in the prevalence of asthma in men from different provinces has been reported before in Swedish male conscripts, ${ }^{45}$ in whom the prevalence of asthma in the northern region (including Jämtland) was almost double that of the central region where Gävleborg is situated. This greater asthma prevalence in the colder climate was attributed to an unhealthy indoor climate. However, this seems less plausible if it only applies to men. We have recently found a high prevalence of asthma-associated symptoms and selfreported asthma, as well as bronchial hyperreactivity, in cross country skiers ${ }^{4647}$ and suggest that a greater exposure to cold and dry air in combination with exercise causes these symptoms in skiers. As men in northern Sweden probably spend more time out of doors working as well as off duty (hunting and fishing are popular elements of the "male culture"'), it is possible that they are exposed to asthma-provoking factors more often than are men in more southerly areas, resulting in a greater prevalence of asthma.

Even though most subjects classified as having asthma had consulted a doctor about their airway symptoms, only about half of 16 year olds, and even fewer older subjects, reported a physician's diagnosis of asthma. Underdiagnosis of asthma has previously been reported from several countries and seems to be as prevalent in Sweden as elsewhere. ${ }^{4048}$

We also found asthma to be undertreated. Only $60 \%$ of the youngest asthmatic subjects reported the use of inhaled $\beta_{2}$ agonists during the year before the examination. We believe that most of them would have benefited from such treatment. Of the 104 asthmatic subjects aged 16 reporting symptoms on most days, or even nightly symptoms, $44 \%$ had used $\beta_{2}$ stimulants during the week before the examination and only $9 \%$ had used inhaled steroids, with only minor differences between the provinces.

In conclusion, the differences in the use of antiasthmatic medication between the counties of Jämtland and Gävleborg mainly reflect a difference in the prevalence of obstructive airway disease. Undertreatment of asthma occurs in both counties and several individuals with significant obstructive airway disease do not use any medication. The use of regular medication is infrequent among asthmatic patients, particularly in the younger age groups. A more frequent use of inhaled steroids among asthmatic subjects and among those with COPD in Jämtland contributes to the observed differences. Differences in consultation rate and rate of diagnosis does not seem to play an important part in explaining the differences in medication. Dosage levels as well as differences in treatment principles may, however, influence the total consumption.

This study was made possible through grants from the National Corporation of Pharmacies and The King Oscar II:s Jubilee Fund. Salbutamol (Ventolin), spacers, and peak flow meters were provided by Glaxo Sweden AB. Equipment for methacholine challenge was provided by Aiolos Medicinsk Teknik AB, Karlstad, Sweden. Ivars Bil AB provided the Jämtland testing team with a car. We are indebted to Ulla Bidner, Inga-Britt Gillström, Aino Johansson, Annica Nygren, Märit Persson, and Maj Asgårdh for performing interviews and tests and for secretarial and administrative assistance.

1 Charpin D, Vervloet D, Charpin J. Epidemiology of asthma in western Europe. Allergy 1988;43:481-92.

2 Larsson L, Boëthius G, Uddenfeldt $M$. Differences in utilization of asthma drugs between two neighbouring Swedish provinces: relation to symptom reporting. Eur Respir f 1993;6:198-203.

3 American Thoracic Society. Standardization of spirometry - 1987 update. Am Rev Respir Dis 1987;136:1285-98.

4 Solymar L, Aronsson P-H, Bake B, Bjure J. Nitrogen single breath test, flow-volume curves and spirometry in healthy breath test, flow-volume curves and spirometry in healthy
children, 7-18 years of age. Eur $₹$ Respir Dis 1980;61:27586.

5 Berglund E, Birath G, Grimby G, Kjellmer I, Sandqvist L, Söderholm B. Spirometric studies in normal subjects. Acta Med Scand 1963;173:185-92.

6 Higgins BG, Britton JR, Chinn S, Cooper S, Burney PGJ, Tattersfield AE. The distribution of peak expiratory flow variability in a population sample. Am Rev Respir Dis 1989;140:1368-72.

7 Löwhagen O, Lindholm NB. Short-term and long-term variation in bronchial response to histamine in asthmatic patients. Eur $\mathcal{Y}$ Respir Dis 1983;64:466-72.

8 American Thoracic Society. Standards for the diagnosis and care of patients with chronic obstructive pulmonary and care of patients with chronic obstructive pulmonary
disease (COPD) and asthma. Am Rev Respir Dis disease (COPD)

9 Ruggieri F, Hindle $M$. Diagnosis and treatment of asthma across Europe. Eur Respir $\mathcal{F} 1989 ; 2: 536 \mathrm{~s}-539 \mathrm{~s}$.

10 Svensk Läkemedelsstatistik (Drug sale statistics in Sweden). Apoteksbolaget Stockholm (yearly publication, in Swedish).

11 Anderson HR, Pottiere AC, Strachan DP. Asthma from birth to age 23: incidence and relation to prior and concurrent atopic disease. Thorax 1992;47:537-42.

12 Clausen JL. The diagnosis of emphysema, chronic bronchitis, and asthma. Clin Chest Med 1990;11:405-16.

13 Rijcken B, Schouten JP, Rosner B, Weiss ST. Is it useful to distinguish between asthma and chronic obstructive pulmonary disease in respiratory epidemiology? Am Rev Respir Dis 1991:1456-7.

14 Mortagy AK, Howell JBL, Waters WE. Respiratory symptoms and bronchial reactivity: identification of a syntrome and its relation to asthma. $B M Y$ 1986;293:525-9.

15 Corrao WM, Braman SS, Irwin RS. Chronic cough as the sole presenting manifestation of bronchial asthma. $N$ Engl f Med 1979;300:633-7.

16 Woolcock A. Epidemiological methods for measuring prevalence of asthma. Chest 1987;91(Suppl 6):89S-93S.

17 Lundbäck B, Stjernberg N, Nyström L, Lundbäck K, Lindström M, Rosenhall $L$. An interview study to estimate prevalence of asthma and chronic bronchitis. The Obstructive Lung Disease in Northern Sweden study. Eur ₹ Epidemiol 1993;9:123-33.

18 Lundbäck B, Stjernberg N, Rosenhall L, Lindström M, Jönsson E. Methacholine reactivity and asthma. Report from the Northern Sweden Obstructive Lung Disease project. Allergy 1993;48:117-24.

19 Hetzel MR, Clark TJH. Comparison of normal and asthmatic circadian rhythms in peak expiratory flow rate. Thorax 1980;35:732-8.

20 Quackenboss JJ, Lebowitz MD, Krzyzanowski M. The normal range of diurnal changes in peak expiratory flow rates. Relationship to symptoms and respiratory disease. rates. Relationship to symptoms and

21 Pauwels R, Joos G, Van Der Straeten M. Bronchial hyperresponsiveness is not bronchial hyperresponsiveness is not bronchial asthma. Clin Allergy 1988;18:317-21. 
22 Britton J. Is hyperreactivity the same as asthma? Eur Respir f 1988;1:476-91.

23 Baumann UA, Haerdi E, Keller R. Relations between clinical signs and lung function in bronchial asthma: how is acute bronchial obstruction reflected in dyspnoea and wheezing? Respiration 1986;50:294-300.

24 Rubinfeld AR, Pain MCF. How mild is mild asthma? Thorax 1977;32:177-81.

25 Barnes PJ. Poorly perceived asthma. Thorax 1992;47:408-9. 26 Toelle BG, Peat JK, Salome CM, Mellis CM, Woolcock AJ. Toward a definition of asthma for epidemiology. Am Rev Respir Dis 1992;146:633-7.

27 Filuk RB, Easton PA, Anthonisen NR. Response to large doses of salbutamol and theophylline in patients with chronic obstructive pulmonary disease. Am Rev Respir chronic obstructive

28 Anthonisen NR, Wright EC and the IPPB Trial group. Response to inhaled bronchodilators in COPD. Chest 1987;5:36s-39s.

29 Ramsdale EH, Morris MM, Roberts RS, Hargreave FE. Bronchial responsiveness to methacholine in chronic bronchitis: relationship to airflow obstruction and cold air responsiveness. Thorax 1984;39:912-8.

30 Yan K, Salome CM, Woolcock A. Prevalence and nature of bronchial hyperresponsiveness in subjects with chronic obstructive pulmonary disease. Am Rev Respir Dis 1985;132:25-9.

31 Ramsdale EH, Morris MM, Hargreave FE. Interpretation of the variability of peak flow rates in chronic bronchitis. of the variability of pea

32 Meslier N, Racineux JL, Six P, Lockhart A. Diagnostic value of reversibility of chronic airway obstruction to separate asthma from chronic bronchitis: a statistical approach. Eur Respir f 1989;2:497-505.

33 Julin A, Wilhelmsen L. Bronchial asthma and chronic bronchitis in a random population sample. Scand $\mathcal{f}$ Respir Dis 1967;48:330-42.

34 Kiviloog J, Irnell L, Eklund G. The prevalence of bronchial asthma and chronic bronchitis in smokers and nonsthokers in a representative local Swedish population. Scand $\mathcal{F}$ Respir Dis $1974 ; 55: 262-76$.

35 Bakke PS, Baste V Hanoa R, Gulsvik A. Prevalence of obstructive lung disease in a general population: relation to occupational title and exposure to some airborne gents. Thorax 1991;46:863-70.

36 Vesterinen E, Kaprio J, Koskenvuo M. Prospective study of asthma in relation to smoking habits among 14729 adults. Thorax 1988;43:534-9.

37 Pöysä L, Korppi M, Pietikäinen M, Remes K, JuntunenBackman K. Asthma, allergic rhinitis and atopic eczema in Finnish children and adolescents. Allergy 1991;46:1615.

38 Woolcock AJ, Peat JK, Salome CM, Yan K, Anderson SD Schoeffel RE, et al. Prevalence of bronchial hyperresponsiveness and asthma in a rural adult population. Thorax 1987;42:361-8.

39 Peat JK, Haby M, Spijker J, Berry G, Woolcock AJ. Prevalence of asthma in adults in Busselton, Western Australia. BMF 1992;305:1326-9.

40 Sears MR. Epidemiological trends in bronchial asthma. In Kaliner MA, Barnes PJ, Persson CGA, eds. Asthma, its pathology and treatment. Lung biology in health and disease. Volume 49. New York: Dekker, 1991:1-49.

41 Gergen PJ, Mullally DI, Evans R. National survey of asthma among children in the United States, 1976 to 1980. Pediatrics 1988;81:1-7.

42 Gregg I. Epidemiological aspects. In: Clark TJH, Godfrey S, eds. Asthma. London: Chapman and Hall, 1983:24284.

43 Norrman E, Rosenhall L, Nyström L, Bergström E Stjernberg $\mathbf{N}$. High prevalences of asthma and related symptoms in teenagers in northern Sweden. Eur Respir $\mathcal{F}$ 1993;6:834-9.

44 Alanko K. Prevalence of asthma in a Finnish rural population. Scand F Respir Dis 1970; Suppl 76: 7-64.

45 Åberg N. Asthma and allergic rhinitis in Swedish conscripts. Clin Exp Allergy 1989;19:59-63.

46 Larsson L, Hemmingsson P, Boëthius G. Self-reported obstructive airway symptoms are common in young crosscountry skiers. Scand $\mathcal{f}$ Med Sci Sports (in press).

47 Larsson $\mathrm{K}$, Ohlsén $\mathrm{P}$, Larrson L, Malmberg $\mathrm{P}$, Rydström PO, Ulriksen $H$. High prevalence of asthma in crosscountry skiers. $B M \mathcal{F}$ (in press).

48 Burney PGJ. Epidemiology. In: Clark TJH, Godfrey S Lee TH, eds. Asthma. 3rd edn. London: Chapman and Hall, 1992:254-307. 